\title{
ASSESSMENT OF RIVERINE DEGRADATION
}

\author{
PR Attygalle \\ River Basin Management Division, Mahaweli Authority of Sri Lanka, Colombo 10
}

Sri Lanka is blessed with one hundred and three rivers that originate from the central hills. Only a few of these are perennial. Eighty flows through the dry zones of Sri Lanka. Mahaweli is the only perennial river that traverses the Northern Dry Zone. Under the Mahaweli Restructuring \& Rehabilitating Project (MRRP), Mahaweli Authority (MA) is to be transformed into a Mahaweli River Basin Management Agency (MRBMA). The key issue that needs to be addressed by this proposed agency has been identified. Riverine degradation has been one of those.

MA's pilot activities on river basin management have been concentrated to the Kala Oya Basin that includes System $\mathrm{H}$ as well. Thus considering Kala Oya Basin as a pilot study area a framework has been proposed to assess the riverine degradation.

Riverine zone includes river/stream banks and rivet/stream reservations. In addition to the directed human impact on this zone the activities that take place in the river/stream also influence the health of the Riverine zone. Further variation in flow regime and velocity too, influence the status of the zone.

While outlining the causes of riverine degradation, the paper highlights the importance of assessing four components, vegetation, land, stream flow and human that influence the levels of degradation in the riverine zone.

Finally three indices have been proposed to assess the levels of degradation in the riverine zone. 